\title{
Multi-temporal LiDAR-DTMs as a tool for modelling a complex landslide: a case study in the Rotolon catchment (eastern Italian Alps)
}

\author{
G. Bossi ${ }^{1}$, M. Cavalli ${ }^{1}$, S. Crema ${ }^{1}$, S. Frigerio ${ }^{1}$, B. Quan Luna ${ }^{2}$, M. Mantovani ${ }^{1}$, G. Marcato ${ }^{1}$, L. Schenato ${ }^{1}$, and \\ A. Pasuto ${ }^{1}$ \\ ${ }^{1}$ CNR-IRPI - National Research Council of Italy, Research Institute for Geo-Hydrological Protection, Padova, Italy \\ ${ }^{2}$ DNV GL - Strategic Research and Innovation, Høvik, Norway
}

Correspondence to: G. Bossi (giulia.bossi@irpi.cnr.it)

Received: 24 September 2014 - Published in Nat. Hazards Earth Syst. Sci. Discuss.: 10 October 2014

Revised: 25 February 2015 - Accepted: 17 March 2015 - Published: 1 April 2015

\begin{abstract}
The geomorphological change detection through the comparison of repeated topographic surveys is a recent approach that benefits greatly from the latest developments in topographical data acquisition techniques. Among them, airborne LiDAR makes the monitoring of geomorphological changes a more reliable and accurate approach for natural hazard and risk management. In this study, two LiDAR digital terrain models (DTMs) ( $2 \mathrm{~m}$ resolution) were acquired just before and after a complex $340000 \mathrm{~m}^{3}$ landslide event (4 November 2010) that generated a debris flow in the channel of the Rotolon catchment (eastern Italian Alps). The analysis of these data was used to set up the initial condition for the application of a dynamic model.

The comparison between the pre- and post-event DTMs allowed us to identify erosion and depositional areas and the volume of the landslide. The knowledge of the phenomenon dynamics was the base of a sound back analysis of the event with the 3-D numerical model DAN3D. This particular code was selected for its capability to modify the rheology and the parameters of the moving mass during run-out, as actually observed along the path of the 2010 debris flow.

Nowadays some portions of Mt. Rotolon flank are still moving and show signs of detachment. The same soil parameters used in the back-analysis model could be used to simulate the run-out for possible future landslides, allowing us to generate reliable risk scenarios useful for awareness of civil defense and strategy of emergency plans.
\end{abstract}

\section{Introduction}

Recent improvements in topographical data acquisition techniques and software allow us to derive high-resolution digital terrain models (DTMs) and develop new methodologies for analyzing earth surface processes (e.g. McKean and Roering, 2004; Lane et al., 2004; Lashermes et al., 2007; Iwahashi et al., 2012; Cavalli et al., 2013; Tarolli, 2014). Among these techniques, light detection and ranging (LiDAR) is probably the most important technological innovation for geomorphic research (Roering et al., 2013) and, in the last years, its applications in geomorphology and natural hazard fields have significantly increased (Notebaert et al., 2009; Jaboyedoff et al., 2012; Roering et al., 2013). In particular, comparisons of LiDAR-derived DTMs obtained from successive surveys make it possible to produce DEM of differences (DoD) maps, which are a valuable tool to interpret the evolution of geomorphological processes and to quantitatively assess morphological changes due to erosion and deposition on rivers (Lane et al., 2003; Wheaton et al., 2010; Picco et al., 2013;) and in case of debris flows (Scheidl et al., 2008; Theule et al., 2012; Blasone et al., 2014) and landslides (Burns et al., 2010; DeLong et al., 2012).

Another tool broadly used to investigate the dynamics of geomorphological processes is numerical modelling (Hungr et al., 2005, Rickenmann, 2005). Dynamic run-out models can simulate the propagation of material after initial failure and delineate the zones where elements at risk will suffer an impact with a certain level of intensity (Quan Luna et al., 2011). The results of these models are used as in- 
put for vulnerability and risk assessments (van Westen et al., 2006). However, numerical models rely on back analysis for validation and the accuracy of results is still not optimal. An important feature of run-out models is the possibility to perform forward analyses (Bossi et al., 2013) and forecast changes in hazards (Crosta et al., 2006). Dynamic computer models have the potential to simulate geomorphological processes with an acceptable degree of accuracy. Once this is achieved, a range of potential hazard scenarios can be analyzed and the results can be used to inform local authorities and the population in order to respond to these hazards and plan the reduction of associated risks (Quan Luna et al., 2014). To model properly the run-out pattern of the flow material during its downslope movement, detailed topographic information from the sliding track and the source zone is needed. Formerly, DTMs for landslide investigation were realized through GPS surveys (Marcato et al., 2006) or derived from contour lines and photogrammetry (Sosio et al., 2008). Nowadays, an improvement in the precision of the DTMs can be expected by using laser scanning techniques such as LiDAR. This will avoid the problem of the lack of accuracy of the DTMs and the stochastic changes in topography during the run-out process (van Asch et al., 2007). In this paper we report the use of DoD maps as a base to calibrate a 3-D model, using the numerical code DAN3D (McDougall and Hungr, 2004), of a large debris flow event that occurred on 4 November 2010 in the eastern Italian Alps.

\section{Study area}

The Rotolon catchment is located in north-eastern Italy (Veneto region, Italy) and covers an area of $5 \mathrm{~km}^{2}$ (Fig. 1). The valley stretches along an s-shape from 1930 down to $590 \mathrm{~m}$ a.s.l., where the touristic village of Recoaro Terme is located. The basin is bordered by mountains made of sedimentary rocks Triassic in age (from Scythian to Rhaetian) such as dolomite, limestone, sandstones, marls and gypsum. These lithotypes show evident signs of weathering and are affected by joints and fractures. Mainly rhyolite but also breccia and tuff are present, while igneous rocks rarely appear.

Thick deposits cover the upper part of the basin. Some of the deposits originate from rock falls detached from the dolomitic and calcareous formation and others from the underlying altered strata of clayey marls. Steep slopes characterize these deposits, thus predisposing the sediments to mass movement events (Altieri et al., 1994).

The instability phenomena occurring in the Rotolon catchment are linked with the presence of a large deep-seated gravitational slope deformation with a volume of several million cubic metres. The type of movements in the upper part are various: falls, topples and rotational slides that sometimes evolve into debris flow along the Rotolon stream. The vulnerable elements in the catchment are two villages set beside the channel (namely Turcati and Parlati), two bridges and some

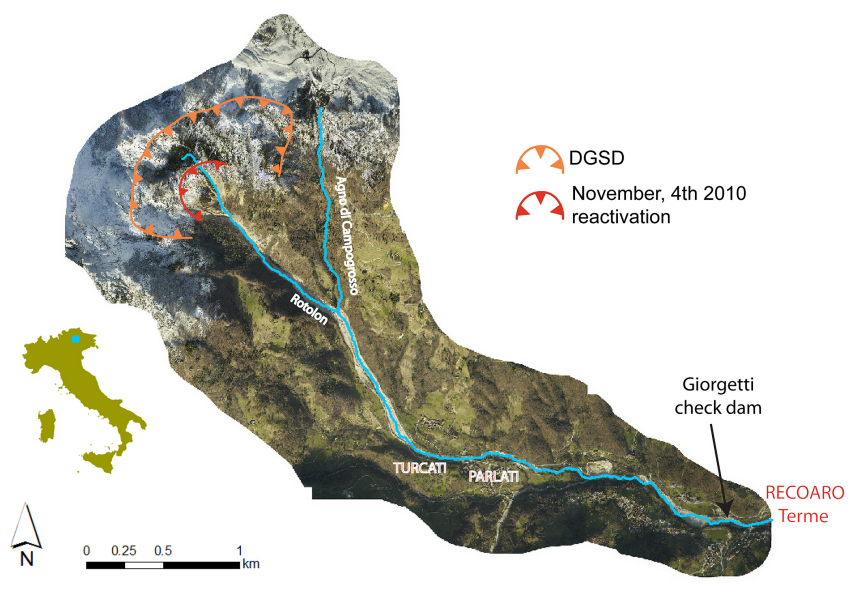

Figure 1. Study area: post-event orthophoto with the main hydrographic network and the landslides crowns highlighted.

road sections, along with the city of Recoaro Terme that is located farther downstream (Fig. 1).

Several important debris flow events have been documented in the Rotolon catchment since 1798. In 1985, a large reactivation led to a renewed interest in the phenomenon mainly aimed at the definition of possible mitigation measures. More recently, in 2009, a debris flow threatened the village of Turcati, depositing in the channel a volume of $30000 \mathrm{~m}^{3}$ of debris. In the last event, which occurred on 4 November 2010 , a mass of $340000 \mathrm{~m}^{3}$ detached as a rotational slide from the flanks of Mt. Carega and partially evolved into a debris flow along the main channel. This event produced a channel aggradation of about $3 \mathrm{~m}$ near the villages of Turcati and Parlati, causing alarm among the population.

An automatic monitoring network (Frigerio et al., 2014) and an early-warning system (Bossi et al., 2015) have been implemented to mitigate the hazard and protect the exposed population. It was crucial to obtain a reliable numerical reconstruction of the event in order to select the more appropriate material properties to use for defining risk scenarios and to design mitigation measures.

\section{Methods}

\subsection{DoD}

Two LiDAR surveys have been conducted in the Rotolon catchment by the Soil Defence Department of the Veneto region. The first was carried out on 21 October 2010 by the regional authority just 13 days before the event, and the second with the same characteristics (i.e. sensors, flight parameters, average point density) was carried out on 23 November. The average point density for both surveys was about $8 \mathrm{pts} \mathrm{m}^{-2}$ while the vertical accuracy (root mean square error) of laser data was 0.072 and $0.044 \mathrm{~m}$ for the October and 


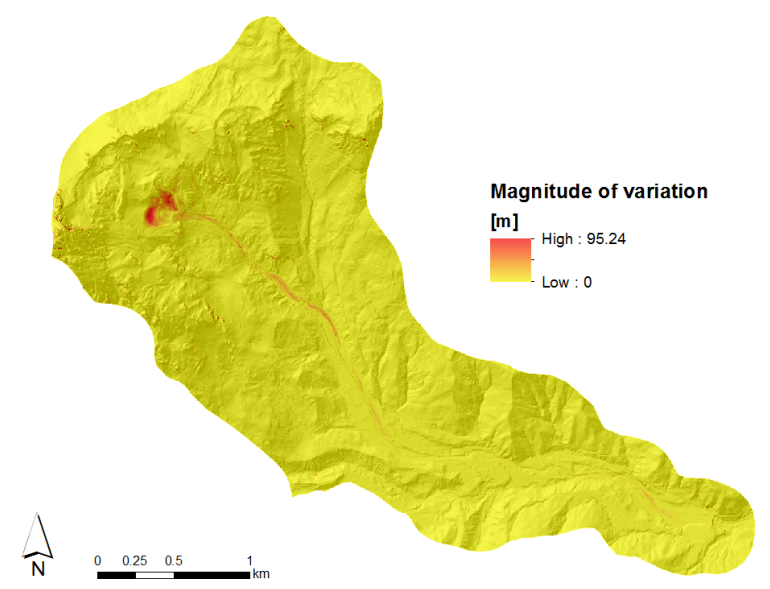

Figure 2. Magnitude of geomorphic change in the Rotolon catchment.

November surveys respectively. The available data consisted of 11 ASCII files already interpolated with a triangulation algorithm and then resampled with linear interpolation on a $2 \times 2 \mathrm{~m}$ grid. The 11 files were then converted into ESRI raster format and merged into a single DTM with particular attention to the spatial coherence of the two surveys.

A first comparison between the pre- and post-event DTMs was carried out with the Change Vector Analyses tool implemented in the open-source GIS Whitebox 2.0.2 (http://www. uoguelph.ca/ hydrogeo/Whitebox/). The tool calculates the magnitude (Fig. 2) and the direction of variation (erosion or deposit) by simply subtracting the two topographic surfaces. The resulting rasters show clearly the pattern of the event but are also affected by noise mainly related to the vertical and horizontal accuracy of the LiDAR data (Cavalli and Tarolli, 2011) and to the different results of the filtering process applied to remove LiDAR points belonging to vegetation and buildings in the two raw data sets. Therefore, error propagation was taken into account before quantitative comparisons of sequential DTMs. Both magnitude and direction of variation maps were used to draw a boundary of the area affected by the event in order to focus the DoD analysis where the most evident morphologic variations occurred.

For the DoD analysis, the software GCD 5 (Geomorphic Change Detection, plug-in version for ArcGIS) was used (Wheaton et al., 2010). In the code, several methods to calibrate the DoD calculation are presented. In order to adopt an approach based on the spatially variable assessment of the error, it is necessary to have information about spatially variable DTM quality that is strictly related to the quality of the survey data (Wheaton et al., 2010). Since original LiDAR point clouds were not available, the evaluation of spatial uncertainty in each individual DTM was not possible and a simple minimum level of detection ( $\min \mathrm{LoD}$; Brasinghton et al., 2000, Fuller et al., 2003) approach, considering a uniform error, was used. Predicted elevation changes that occurred beneath $\min$ LoD were discarded, whereas elevation changes above this limit were treated as real. Brasington et al. (2003) showed the individual errors in the DEMs can be propagated into the DoD as

$\delta u_{\mathrm{DoD}}=\sqrt{\left(\delta z_{\text {new }}\right)^{2}+\left(\delta z_{\text {old }}\right)^{2}}$

where $\delta u_{\mathrm{DoD}}$ is the propagated error in the DoD and $\delta z_{\text {new }}$ and $\delta z_{\text {old }}$ are the individual errors of the post- and pre-event DTM respectively. For the analysis, the error in both DTMs was set at $0.2 \mathrm{~m}$, the usual error of airborne LiDAR DTM (Cavalli and Tarolli, 2011), and considered as uniformly distributed.

\subsection{Numerical method}

The 3-D simulation was performed with the DAN3D software (Hungr and McDougall, 2009) which uses an adapted smoothed particle hydrodynamics approach. The rock mass is discretized into numerous particles that flow forced by topography, based on a selected rheology.

A 3-D modelling code was necessary for modelling the Rotolon landslide as the peculiar course of the river alters the dynamic of the flow, with marked effects of path curvature in the erosion/deposition pattern. Among 3-D codes, DAN3D was chosen because it allows us to modify the rheology of the landslide along the path. The DTM on which the process is simulated could be divided in different zones in which the properties of the flowing mass and the substrate are assigned. This was crucial because the dynamic of the Rotolon landslide was complex and it was necessary, for example, to recreate the fluidification mechanism caused by the inlet of the Agno di Campogrosso (hereafter called Agno), a secondary stream. In fact, the Agno inlet was considered a separation zone between the upper and lower part of the landslide track. Moreover, DAN3D allows us to consider entrainment of material during the process and permits us to select the maximum erosion depth for each zone of the track. The mechanism of entrainment follows an empirical approach based on the parameter $\mathrm{E}$ (erosion rate, $\left[\mathrm{m}^{-1}\right]$ ), which represents the increase of the volume of the flowing mass per unit of distance travelled (McDougall and Hungr, 2005).

The modelling of the Rotolon landslide followed a backanalysis procedure. The soil parameters are selected through trial and error on the basis of the DoD data analysis. In DAN3D the input files are a source area file, which represents the initial geometry of the sliding mass, and the topography file. The availability of pre- and post-DTM files allowed us to greatly reduce the uncertainties connected with these data, as the source file was clearly highlighted in the DoD map and the pre-event DTM was an almost no-error topography file. However, in order to reduce the computational time of the simulation, the cells were resampled onto a $5 \times 5 \mathrm{~m}$ grid. 


\section{Results}

\subsection{DoD analysis}

The resulting differential DTM (Fig. 3) was analyzed in order to identify erosion and depositional areas related to the event and to quantify them in terms of volume (Fig. 4). Main results are listed in Table 1.

Results show a sort of balance between deposition and erosion within the catchment with a total erosion of $400000 \mathrm{~m}^{3}$. The 2010 event detached a mass of $340000 \mathrm{~m}^{3}$ from the main source area in the upper part of the catchment. This mass partially evolved in a debris flow that stretched for $4.5 \mathrm{~km}$, threatening some villages. The total net volume difference of $15000 \mathrm{~m}^{3}$ could be considered as bed load transport at the catchment outlet. Nevertheless, it is worth noting the high error associated with the total net volume (i.e. \pm 51.347 ).

\subsection{The event as described by the DoD}

The dynamic of the 2010 event was quite complex due to the morphology of the valley, the type of sediment involved and the amount of detached material (about $340000 \mathrm{~m}^{3}$ ).

Just after the detachment, part of the material $\left(20000 \mathrm{~m}^{2}\right)$ stopped against the upper left flank, filling a small depression and not contributing to the flow along the Rotolon stream. The other $320000 \mathrm{~m}^{3}$ fell down in a track characterized by a $27^{\circ}$ slope, thus acquiring further energy. Moreover, the presence of a bend along the channel caused erosion on the external part of the river bed due to the effect of transversal velocities. This caused two small lateral failure on the left bank. Later on, in a $900 \mathrm{~m}$ long and $15^{\circ}$ inclined track located upstream Agno di Campogrosso inlet, $186000 \mathrm{~m}^{3}$ of material settled. Here the total erosion was $21000 \mathrm{~m}^{3}$, leaving $155000 \mathrm{~m}^{3}$ of sediment entering the flatter part of the valley.

The DoD analysis shows that from the Agno di Campogrosso inlet the material flowed for another $3 \mathrm{~km}$ in a $7^{\circ}$ inclined channel, depositing $149000 \mathrm{~m}^{3}$ of material. This suggests that there was a modification of the rheology of the flowing mass due to the increase of water content. Data show that the large Giorgetti check dam (Fig. 1), located just upstream of the city of Recoaro Terme, represents the last section along the Rotolon stream in which a significant deposition occurred.

\subsection{Modelling}

The coupling of frictional and turbulent behaviour allows us to better describe the complex dynamic of the landslide and its long travel distance associated with more than $10 \%$ of entrainment. Therefore, during the calibration process a Voellmy rheology (Voellmy, 1955) was selected for the model:

$\tau_{z x}=-\left(f \sigma_{z}+\frac{\rho g v_{x}^{2}}{\xi}\right)$,

where $f$ is the friction coefficient $\left(f=\tan \varphi_{\mathrm{b}}\right.$ with $\varphi_{\mathrm{b}}$ bulk basal friction angle) and $\xi$ the turbulence parameter. For the upper part a friction coefficient of $f=0.18$ and a turbulence parameter of $\xi=200 \mathrm{~m} \mathrm{~s}^{-2}$ were selected, whereas $f=0.05$ and $\xi=200 \mathrm{~m} \mathrm{~s}^{-2}$ were used for the lower part. These are typical parameters for the modelling of a debris flow in alpine environment (Quan Luna et al., 2013). Moreover, an erosion rate of 0.0001 has been imposed, with a maximum erosion depth of $5 \mathrm{~m}$ in the upper part of the track.

As the kinematics of the phenomenon in the detachment area was complex, with the left bank movement difficult to simulate with the same code, our model focused on reconstructing the dynamic and deposition pattern along the channel track, and the results show a good correspondence with the DoD data (Fig. 5). Actually, the volume deposited in the upper section was $196000 \mathrm{~m}^{3}$, while it was $152000 \mathrm{~m}^{3}$ in the lower tract. The errors are therefore $10000 \mathrm{~m}^{3}$ upstream from the Agno di Campogrosso inlet and just $3000 \mathrm{~m}^{3}$ downstream. This is an acceptable accuracy for the modelling of a large landslide. Nevertheless, the deposition pattern is not perfectly reconstructed; the biggest discrepancy is located just after the Agno di Campogrosso inlet. In the real event the fluidification process took some space and time to develop, with a marked transversal dynamic of deposition in the external part of the curve and erosion in the intern, where the clear water would have likely flown. In fact, from the upper track a flow with a fairly high angle of friction arrives. Then, two events simultaneously occur at the bend: the channel slope changes significantly from 15 to $7^{\circ}$, and the water discharge from the Agno di Campogrosso enters in the main channel. The water flow from the Agno di Campogrosso is directed to the internal part of the bend, thereby fluidifying the internal flow and allowing it to maintain momentum to carry more sediments and also to erode. However, the material flowing on the external part of the bend would have undergone a less significant change in the rheology, thereby depositing more quickly due to the change of channel slope and also to the lesser velocities. In the model, contrarily, the modification of the rheology is immediate and this kind of phenomenon is not recreated properly. Therefore, in the map of the deposits derived from the DAN3D simulation, the levee of the deposit downstream from the Agno di Campogrosso inlet is not present. Another smaller difference is located in the channel upstream from the Agno di Campogrosso inlet: even though the deposition is coherent with the $\mathrm{DoD}$ for thickness and shape of the deposit, a smearing effect at the border is present with a $20 \mathrm{~m}$ buffer outside the DoD deposit contour. Eventually, the material did not reach the Giorgetti dam. This discrepancy may be explained by the time lag (19 days) between the actual event and the post-event LiDAR survey: it is presumable that some sediment transport occurred after the 
Table 1. Main results of the DoD analysis.

\begin{tabular}{|c|c|c|c|c|}
\hline Attribute & Raw & \multicolumn{3}{|c|}{ DoD estimate with threshold } \\
\hline \multicolumn{5}{|l|}{ Areal } \\
\hline Total area of erosion $\left(\mathrm{m}^{2}\right)$ & 114.900 & 91.732 & & \\
\hline Total area of deposition $\left(\mathrm{m}^{2}\right)$ & 180.276 & 156.656 & & \\
\hline Volumetric & & & \pm Error volume & $\%$ Error \\
\hline Total volume of erosion $\left(\mathrm{m}^{2}\right)$ & 404.048 & $400.890 \pm$ & 25.946 & $6 \%$ \\
\hline Total volume of deposition $\left(\mathrm{m}^{2}\right)$ & 387.705 & $384.551 \pm$ & 44.309 & $12 \%$ \\
\hline Total volume of difference $\left(\mathrm{m}^{2}\right)$ & 791.752 & $785.441 \pm$ & 70.255 & $9 \%$ \\
\hline Total net volume difference $\left(\mathrm{m}^{2}\right)$ & -16.343 & $-16.339 \pm$ & 51.347 & $314 \%$ \\
\hline \multicolumn{5}{|l|}{ Percentages (by volume) } \\
\hline Percent erosion & $51 \%$ & $51 \%$ & & \\
\hline Percent deposition & $49 \%$ & $49 \%$ & & \\
\hline Percent imbalance (departure from equilibrium) & $-1 \%$ & $-1 \%$ & & \\
\hline
\end{tabular}
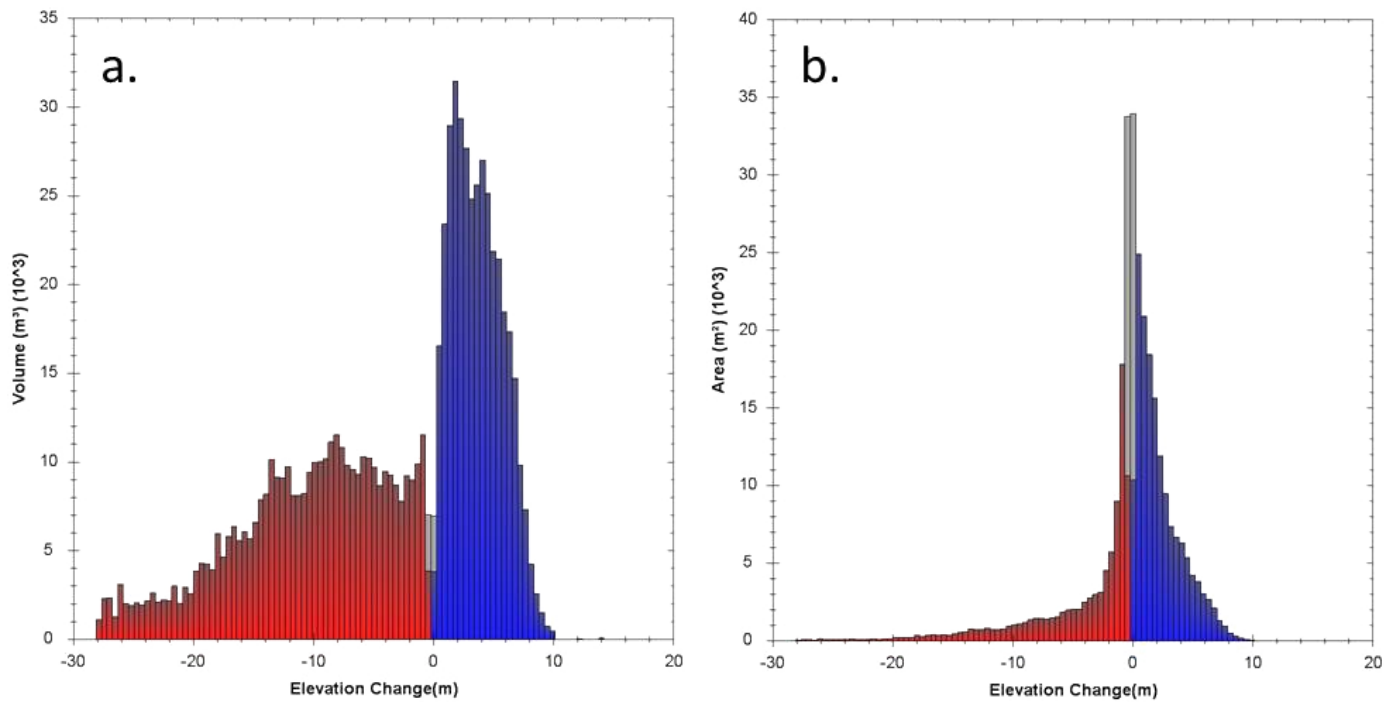

Figure 3. DoD map over shaded relief of the Rotolon catchment.

event and that the deposition front advanced along the channel.

\section{Discussion and conclusions}

In 2013, Worni et al. stated that the future challenges in numerical modelling of flows are linked to the capability of understanding precisely the dynamic of the phenomena and to the availability of high-resolution DTMs. In this paper we present the use of multi-temporal LiDAR DTMs as a tool to analyze mass movement events in each zone of its track in terms of erosion and deposition, obtaining a clear description of the whole process.

The availability of pre- and post-event DTMs allowed us to enhance the consistency of the numerical model and recon- struct the event of 4 November 2010 in the Rotolon catchment. In Table 2 the main results of the simulation are presented: in the track zone, the erosion values are almost equal and the $13000 \mathrm{~m}^{3}$ discrepancy in deposited volume is less than $4 \%$ the total volume of the event.

The DoD approach could thus be used to improve the reliability of back-analysis-based numerical model as the reconstruction of the phenomena usually depends on the definition of a distinct source area, a highly defined pre-event topographic file and a spatially distributed source of information about the erosion/deposition pattern. However, the use of DoD for the analysis of fast-moving flows does not provide the velocities data which are usually obtained through a monitoring system (Arattano and Marchi, 2005). The lack of velocity data is compensated by the information provided 
Table 2. Comparison, in terms of volume, of the main results of the DoD analysis and the DAN3D simulation.

\begin{tabular}{|c|c|c|c|c|c|c|c|c|}
\hline \multirow[t]{2}{*}{ Volume $\left[\mathrm{m}^{3}\right]$} & \multicolumn{3}{|c|}{ DoD } & \multicolumn{3}{|c|}{ DAN3D } & \multicolumn{2}{|c|}{$\begin{array}{l}\text { Difference between DoD } \\
\text { and DAN3D deposit }\end{array}$} \\
\hline & Erosion & Deposit & Balance & Erosion & Deposit & Balance & & \\
\hline Detachment area & & & \multirow{7}{*}{320022} & & & \multirow{7}{*}{313337} & & \\
\hline Main detachment & 342263 & 1915 & & $332123^{*}$ & 17761 & & & \\
\hline Lateral zone & 5227 & 25553 & & & 1025 & & & \\
\hline Mass leaving the detachment area & & & & & & & 6685 & $2.1 \%$ \\
\hline Debris-flow track above the Agno inlet & 21746 & 186523 & & & 196317 & & -9794 & $-5.3 \%$ \\
\hline Debris-flow track below the Agno inlet & 14275 & 149274 & & & 152747 & & -3473 & $-2.3 \%$ \\
\hline Whole debris-flow track & 36021 & 335797 & & 35727 & 349064 & & 13267 & $4.0 \%$ \\
\hline
\end{tabular}

* Source area in DAN3D.

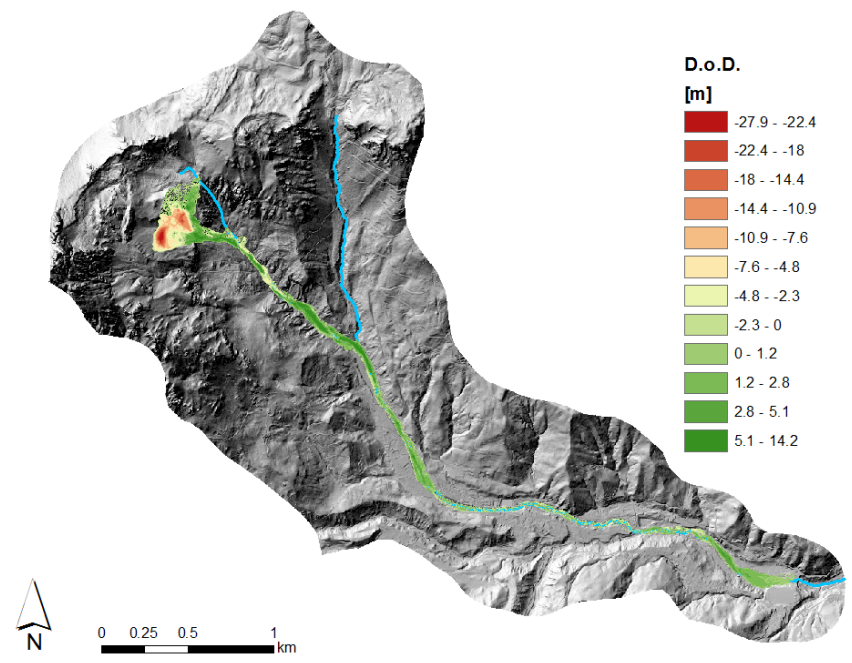

Figure 4. Volumetric and areal distribution of the morphologic variations that occurred between October and November 2010. The deposition is in blue, erosion is in red and the values discarded for the volumetric assessment are in grey.

by the DoD; nevertheless, it is advisable for future studies to also consider the set up of some instruments like ultrasonic, radar, laser sensors or geophones.

The availability of a pre-event LiDAR survey acquired 13 days before the reactivation was a lucky coincidence and represents the best possible condition. It was possible to simulate the flow over a topographical surface that was not altered by sediment transport processes occurring naturally in the catchment, smaller landslides or human interference. In usual practice, however, requesting a post-event LiDAR survey is relatively easy, while the possibility of obtaining a pre-event DTM depends on the capability of sustaining the economical effort of periodic flights, although their cost has dramatically decreased (Reutebuch et al., 2005). Thus a rational approach could be to investigate the whole territory as measure zero and then concentrate flights for post-event assessment or in periodic surveys on event-prone areas, where a consistent

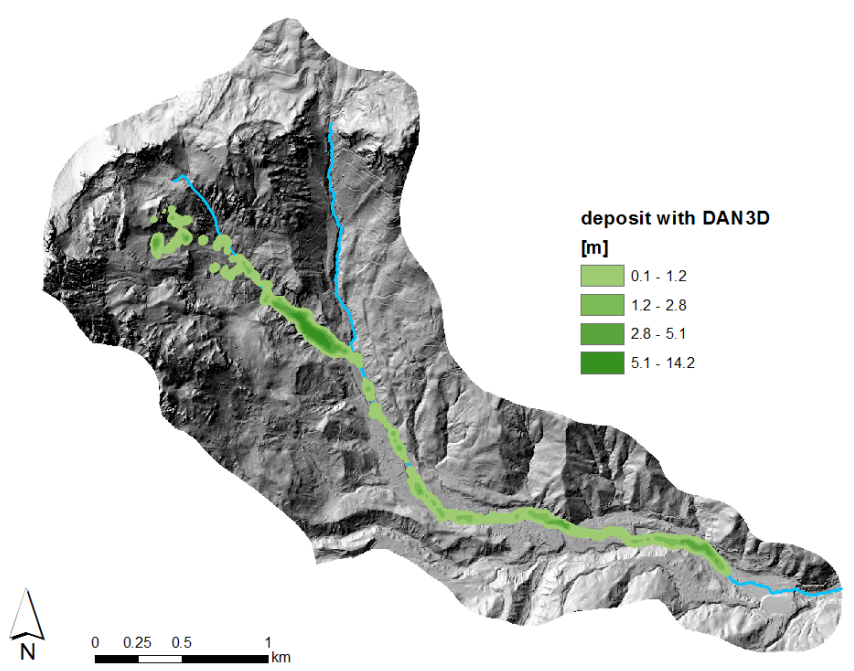

Figure 5. Results of the back-analysis simulation with DAN3D: distribution of the deposits.

model is necessary to design countermeasure work. The capability of providing a good description of the phenomenon and a reliable numerical model, both describing consistently the whole event from source area to deposition lobes, will also help in evaluating the best options for structural mitigation measures at basin scale. In fact, material properties derived from the back analysis could be used to simulate the run-out of other portions of the landslide that geomorphological analysis indicates are prone to collapse. With this procedure, it is possible to delineate risk scenario even though some errors should be accounted for. In this perspective the integration of DoD analysis with numerical modelling represents a valuable tool for hazard assessment and risk mitigation.

Acknowledgements. The authors wish to thank Patrizio Buscemi from the Difesa del Suolo department of Regione Veneto for providing LiDAR data and the municipality of Recoaro Terme for the technical support. We are also grateful to the editor O. Katz and 
the reviewers M. Mergili and J. Theule for their valuable comments and indications.

Edited by: O. Katz

Reviewed by: M. Mergili and J. Theule

\section{References}

Altieri, V., Colombo, P., and Dal Prà, A.: Studio per la valutazione delle condizioni di stabilità dei versanti e del fondovalle del bacino idrografico del torrente Rotolon nell'alta valle dell'Agno in comune di Recoaro Terme (Vicenza), Regione del Veneto Segreteria Regionale per il Territorio Dipartimento Lavori Pubblici, Venezia, Technical Report (in Italian), 97 pp., 1994.

Arattano, M. and Marchi, L.: Measurements of debris flow velocity through cross-correlation of instrumentation data, Nat. Hazards Earth Syst. Sci., 5, 137-142, doi:10.5194/nhess-5-137$2005,2005$.

Blasone, G., Cavalli, M., Marchi, L., and Cazorzi, F.: Monitoring sediment source areas in a debris flow catchment using terrestrial laser scanning, Catena, 123, 23-36, doi:10.1016/j.catena.2014.07.001, 2014.

Bossi, G., Frigerio, S., Mantovani, M., Schenato, L., Pasuto, A., and Marcato, G.: Hazard assessment of a potential rock avalanche in South Tyrol, Italy: 3-D modeling and risk scenarios, in: Italian Journal of Engineering Geology and Environment - Book Series, Sapienza Università Editrice, 221-227, 2013.

Bossi, G., Crema, S. Frigerio, S., Mantovani, M., Marcato, G., Pasuto, A., Schenato, L., and Cavalli, M.: The Rotolon catchment Early-warning system, in: Engineering Geology for Society and Territory - Volume 3, Springer International Publishing, 91-95, 2015

Brasington, J., Rumsby, B. T., and McVey, R. A.: Monitoring and modelling morphological change in a braided gravel-bed river using high resolution GPS-based survey, Earth Surf. Proc. Land., 25, 973-990, 2000.

Brasington, J., Langham, J., and Rumsby, B.: Methodological sensitivity of morphometric estimates of coarse fluvial sediment transport, Geomorphology, 53, 299-316, doi:10.1016/S0169555X(02)00320-3, 2003.

Burns, W. J., Coe, J. A., Kaya, B. S., and Ma, L.: Analysis of Elevation Changes Detected from Multi-Temporal LiDAR Surveys in Forested Landslide Terrain in Western Oregon, Environ. Eng. Geosci., 16, 315-341, doi:10.2113/gseegeosci.16.4.315, 2010.

Cavalli, M. and Tarolli, P.: Application of LiDAR technology for rivers analysis, in: Italian Journal of Engineering Geology and Environment - Special Issue (1), Sapienza Università Editrice, 33-44, doi:10.4408/IJEGE.2011-01.S-03, 2011.

Cavalli, M., Trevisani, S., Comiti, F., and Marchi, L.: Geomorphometric assessment of spatial sediment connectivity in small Alpine catchments, Geomorphology, 188, 31-41, doi:10.1016/j.geomorph.2012.05.007, 2013.

Crosta, G.B., Chen, H., and Frattini, P.: Forecasting Hazard Scenarios and implications for the evaluation of Countermeasure Efficiency for Large Debris Avalanches, Eng. Geol., 83, 236-253, doi:10.1016/j.enggeo.2005.06.039, 2006.

DeLong, S. B., Prentice, C. S., Hilley, G. E., and Ebert, Y.: Multitemporal ALSM change detection, sediment delivery, and pro- cess mapping at an active earthflow, Earth Surf. Proc. Land., 37, 262-272, doi:10.1002/esp.2234, 2012.

Frigerio, S., Schenato, L., Mantovani, M., Bossi, G., Marcato, G. Cavalli, M., and Pasuto, A.: A Web-based platform for automatic and continuous landslide monitoring: the Rotolon case study, Comput. Geosci., 63, 96-105, doi:10.1016/j.cageo.2013.10.015, 2014.

Fuller, I. C., Large, A. R. G., Charlton, M. E., Heritage, G. L., and Milan, D. J.: Reach-scale sediment transfers: An evaluation of two morphological budgeting approaches, Earth Surf. Proc. Land., 28, 889-903, doi:10.1002/esp.1011, 2003.

Hungr, O. and McDougall, S.: Two numerical models for landslide dynamic analysis, Comput. Geosci., 35, 978-992, doi:10.1016/j.cageo.2007.12.003, 2009.

Hungr, O., Corominas, J., and Eberhardt, E.: Estimating landslide motion mechanism, travel distance and velocity, in: Landslide Risk Management, Taylor and Francis, London, 99-128, 2005.

Iwahashi, J., Kamiya, I., and Yamagishi, H.: High-resolution DEMs in the study of rainfall- and earthquake-induced landslides: Use of a variable window size method in digital terrain analysis, Geomorphology, 153-154, 29-38, doi:10.1016/j.geomorph.2012.02.002, 2012.

Jaboyedoff, M., Oppikofer, T., Abellán, A., Derron, M-H., Loye, A., Metzger, R., and Pedrazzini, A.: Use of LIDAR in landslide investigations: A review, Nat. Hazards, 61, 5-28, doi:10.1007/s11069-010-9634-2, 2012.

Lane, S. N., Westaway, R. M., and Murray Hicks, D.: Estimation of erosion and deposition volumes in a large, gravel-bed, braided river using synoptic remote sensing, Earth Surf. Proc. Land., 28, 249-271, doi:10.1002/esp.483, 2003.

Lane, S. N., Brookes, C. J., Kirkby, M. J., and Holden, J.: A network-index-based version of TOPMODEL for use with highresolution digital topographic data, Hydrol. Process., 18, 191201, doi:10.1002/hyp.5208, 2004.

Lashermes, B., Foufoula-Georgiou, E., and Dietrich, W. E. Channel network extraction from high resolution topography using wavelets, Geophys. Res. Lett., 34, L23S04, doi:10.1029/2007GL031140, 2007.

Marcato, G., Mantovani, M., Pasuto, A., Silvano, S., Tagliavini, F., Zabuski, L., and Zannoni, A.: Site investigation and modelling at "La Maina" landslide (Carnian Alps, Italy), Nat. Hazards Earth Syst. Sci., 6, 33-39, doi:10.5194/nhess-6-33-2006, 2006.

McDougall, S. and Hungr, O.: A model for the analysis of rapid landslide motion across three-dimensional terrain, Can. Geotech. J., 41, 1084-1097, 2004.

McDougall, S. and Hungr, O.: Dynamic modelling of entrainment in rapid landslides, Can. Geotech. J., 42, 1437-1448, doi:10.1139/t05-064, 2005.

McKean, J. and Roering, J.: Objective landslide detection and surface morphology mapping using high-resolution airborne laser altimetry, Geomorphology, 57, 331-351, doi:10.1016/S0169$555 X(03) 00164-8,2004$

Notebaert, B., Verstraeten, G., Govers, G., and Poesen, J.: Qualitative and quantitative applications of LiDAR imagery in fluvial geomorphology, Earth Surf. Proc. Land., 34, 217-231, doi:10.1002/esp.1705, 2009.

Picco, L., Mao, L., Cavalli, M., Buzzi, E., Rainato, R., and Lenzi, M.A.: Evaluating short-term morphological changes in a gravel- 
bed braided river using terrestrial laser scanner, Geomorphology, 201, 323-334, doi:10.1016/j.geomorph.2013.07.007, 2013.

Quan Luna, B., Blahut, J., van Westen, C. J., Sterlacchini, S., van Asch, T. W. J., and Akbas, S. O.: The application of numerical debris flow modelling for the generation of physical vulnerability curves, Nat. Hazards Earth Syst. Sci., 11, 2047-2060, doi:10.5194/nhess-11-2047-2011, 2011.

Quan Luna, B., Cepeda, J., Stumpf, A., Van Westen, C. J., Remaître, A., Malet, J.-P., and van Asch, T. W. J.: Analysis and uncertainty quantification of dynamic run-out model parameters for landslides, in: Landslide Science and Practice: Spatial Analysis and Modelling, Spinger, Berlin Heidelberg, 3, 315-318, doi:10.1007/978-3-642-31310-3_42, 2013.

Quan Luna, B., Blahut, J., Camera, C., van Westen, C. J., Apuani, T., Jetten, V. G., and Sterlacchini, S.: Physically based dynamic run - out modelling for quantitative debris flow risk assessment: a case study in Tresenda, northern Italy, Environ. Earth Sci., 723, 645-661, doi:10.1007/s12665-013-2986-7, 2014.

Reutebuch, S. E., Andersen, H. E., and McGaughey, R. J.: Light detection and ranging (LIDAR): An emerging tool for multiple resource inventory, J. Forest., 103, 286-292, 2005.

Rickenmann, D.: Runout prediction methods, in: Debris-flow Hazards and Related Phenomena, Springer, Berlin, 305-324, 2005.

Roering, J. J., Mackey, B. H., Marshall, J. A., Sweeney, K. E., Deligne, N. I., Booth, A. M., Handwerger, A. L., and CerovskiDarriau, C.: "You are HERE": Connecting the dots with airborne lidar for geomorphic fieldwork, Geomorphology, 200, 172-183, doi:10.1016/j.geomorph.2013.04.009, 2013.

Scheidl, C., Rickenmann, D., and Chiari, M.: The use of airborne LiDAR data for the analysis of debris flow events in Switzerland, Nat. Hazards Earth Syst. Sci., 8, 1113-1127, doi:10.5194/nhess8-1113-2008, 2008.
Sosio, R., Crosta, G. B., and Hungr, O.: Complete dynamic modeling calibration for the Thurwieser rock avalanche (Italian Central Alps), Eng. Geol., 100, 11-26, doi:10.1016/j.enggeo.2008.02.012, 2008.

Tarolli, P.: High-resolution topography for understanding Earth surface processes: Opportunities and challenges, Geomorphology, 216, 295-312, doi:10.1016/j.geomorph.2014.03.008, 2014.

Theule, J. I., Liébault, F., Loye, A., Laigle, D., and Jaboyedoff, M.: Sediment budget monitoring of debris-flow and bedload transport in the Manival Torrent, SE France, Nat. Hazards Earth Syst. Sci., 12, 731-749, doi:10.5194/nhess-12-731-2012, 2012.

van Asch, T. W. J., Malet, J.-P., van Beek, L. P. H., and Amitrano, D.: Techniques, issues and advances in numerical modelling of landslide hazard, B. Soc. Geol. .Fr., 178, 65-88, doi:10.2113/gssgfbull.178.2.65, 2007.

van Westen, C. J., van Asch, T. J. W., amd Soeters, R.: Landslide hazard and risk zonation - why is it still so difficult? -, B. Eng. Geol. Environ., 65, 167-184, doi:10.1007/s10064-005-0023-0, 2006.

Voellmy, A.: Über die Zerstőrunskraft von Lawinen (On breaking force of avalanches), Schweizerische Bauzeitung, 73, 212-285, 1955.

Worni, R., Huggel, C., Dorren, L., and Jaboyedoff, M.: Numerical modeling of flows and falls, in: Treatise on Geomorphology, Academic Press, San Diego, CA, 7, 273-283, 2013.

Wheaton, J. M., Brasington, J., Darby, S. E., and Sear, D. A.: Accounting for uncertainty in DEMs from repeat topographic surveys: improved sediment budgets, Earth Surf. Proc. Land., 35, 136-156, doi:10.1002/esp.1886, 2010. 